\title{
Faktor-faktor yang Berhubungan dengan Kejadian Kanker Serviks di RSUD Arifin Achmad Pekanbaru Tahun 2008-2010
}

\section{Factors Associated with Cervical Cancer Incidence Arifin Achmad Hospital in Pekanbaru Year 2008-2010}

\section{Ika Putri Damayanti}

\section{Program Studi Kebidanan STIKes Hang Tuah Pekanbaru}

\begin{abstract}
ABSTRAK
Kanker serviks adalah tumor ganas primer yang berasal dari sel epitel skuamosa serviks atau leher rahim. Penyebab tersering kanker serviks adalah infeksi virus HPV(Human Papiloma Virus), beberapa faktor yang diduga meningkatkan kejadian kanker serviks yaitu faktor sosiodemografis yang meliputi usia, status sosial ekonomi, dan faktor aktifitas seksual yang meliputi usia pertama kali melakukan hubungan seks, pasangan seks yang berganti-ganti, paritas, kurang menjaga kebersihan genital, merokok, riwayat penyakit kelamin, trauma kronis pada serviks, serta penggunaan kontrasepsi hormonal. Tujuan penelitian ini adalah diketahuinya faktor-faktor risiko yang berhubungan dengan kejadian kanker serviks di RSUD Arifin Achmad Propinsi Riau Tahun 2008-2010. Jenis penelitian yang digunakan adalah kasus kontrol (case control study). Kasus yaitu wanita penderita kanker serviks yang dirawat di RSUD Arifin Achmad Propinsi Riau, dan kontrol yaitu Wanita bukan penderita kanker serviks yang dirawat di RSUD Arifin Achmad Propinsi Riau. Hasil penelitian ini menunjukkan wanita dengan pekerjaan berat lebih beresiko menderita kanker serviks 9 kali dibandingkan dengan wanita yang memiliki pekerjaan ringan (OR 9,184), wanita yang berpendidikan rendah 4 kali lebih berisiko menderita kanker serviks dibandingkan dengan wanita yang berpendidikan tinggi (OR 3,698), wanita yang usia pertama kali berhubungan seksual kurang dari 20 tahun lebih berisiko 3 kali menderita kanker serviks dibandingkan dengan wanita yang usia pertama kali berhubungan seksual diatas 20 tahun (OR 2,792), dan wanita yang memiliki paritas $>3$ anak lebih berisiko 7 kali dibandingakn dengan wanita yang memiliki paritas < anak 3(OR 3,396). Kesimpulan berdasarkan hasil analisis multivariat variabel independen yang memiliki hubungan sebab akibat dengan kejadian kanker serviks adalah pekerjaan, pendidikan, usia pertama kali berhubungan seksual dan paritas. Variabel independen yang tidak memiliki hubungan sebab akibat dengan kejadian kanker serviks adalah ganti pasangan. Dan variabel independen yang confounding dengan kejadaian kanker serviks adalah penggunaan kontrasepsi hormonal, penyakit menular seksual dan usia. Saran ditujukan bagi Dinas kesehatan propinsi riau, RSUD Arifin Achmad Provinsi Riau, masyarakat dan peneliti selanjutnya.
\end{abstract}

Kata Kunci: Kejadian Kanker Serviks, RSUD Arifin Achmad

\begin{abstract}
Cervical cancer is a primary malignant tumor derived from epithelial cells of cervical squamous or cervix. The most common cause of cervical cancer is infection with HPV (Human Papilloma Virus), several factors are thought to increase the incidence of cervical cancer is sosiodemografis factors which include age, socioeconomic status, and sexual activity of factors that include age at first intercourse, partner change sex -replace, parity, lack of genital hygiene, smoking, history of venereal disease, chronic trauma to the cervix, as well as the use of hormonal contraceptives. The purpose of this study are known risk factors associated with cervical cancer incidence in Arifin Achmad Riau Province Year 2008-2010. This type of study is a case-control (case control study). The case of women with cervical cancer who were treated at the Arifin Achmad Riau Province, and control of cervical cancer Women are not treated at the Arifin Achmad Riau Province. The results of this study showed women with heavy work more at risk for developing cervical cancer 9 times compared with women who have jobs lightweight (OR 9,184), low-educated women four times more likely to suffer from cervical cancer compared with women who are highly educated (OR 3,698), female age at first intercourse less than 20 years 3 times higher risk of cervical cancer compared to women with age at first sexual intercourse (OR 2,792)and women above 20 years who had parity> 3 children dibandingakn 7 times greater risk to women with a parity $<3$ children (OR 3,396). As Conclusions, occupation, education, age of first sexual intercourse and parity have based on the results of multivariate analysis of independent variables that have a causal relationship with the incidence of cervical cancer is work, education, age at first sexual intercourse and parity. Independent variables that have no causal relationship with the incidence of cervical cancer is are sexual partners. And independent of confounding variables by are kejadaian incidence of cervical cancer is the use of hormonal contraception, sexually transmitted diseases and age. Advice intended for Riau provincial health office of Riau Province, Arifin Achmad Riau provinceGeneral Hospital, society community and further research.
\end{abstract}

Keywords: the incidence of cervical cancer, Riau provincial health office

Alamat Korespodensi: Ika Putri Damayanti, Prodi Kebidanan STIKes Hang Tuah Pekanbaru, J1 Mustafasari No.05 Tangkerang Selatan Pekanbaru, HP: 08127642289, Email: 


\section{PENDAHULUAN}

Kanker merupakan suatu kondisi sel tubuh kehilangan kemampuannya dalam mengendalikan kecepatan pembelahan dan pertumbuhannya. Jaringan akan tumbuh secara tidak terkontrol dan dapat bersifat fatal (Otto, 2001).

Kanker serviks adalah tumor ganas primer yang berasal dari sel epitel skuamosa. Kanker serviks merupakan kanker yang terjadi pada serviks atau leher rahim, suatu daerah pada organ reproduksi wanita yang merupakan pintu masuk ke arah rahim, letaknya antara rahim (uterus) dan liang senggama atau vagina (Notodiharjo, 2002).

Saat ini kanker serviks menduduki urutan kedua dari penyakit kanker yang menyerang perempuan di dunia dan urutan pertama di negara yang sedang berkembang termasuk Indonesia. Diperkirakan 500.000 kasus baru kanker serviks terjadi setiap tahunnya di dunia, $80 \%$ dari kasus tersebut terdapat dinegara-negara yang sedang berkembang (Aziz, 2006). Menurut data WHO diketahui terdapat 493.243 jiwa pertahun penderita kanker serviks baru di dunia. Dengan angka kematian karena kanker serviks ini sebanyak 273.505 jiwa pertahun (Emilia, 2010).

Di Indonesia Kanker serviks merupakan kanker kedua terbanyak ditemukan pada wanita setelah kanker payudara dan merupakan penyebab kematian utama pada wanita (Aziz, 2006). Kasus baru kanker serviks ditemukan 40-45 kasus perhari dan setiap satu jam seorang perempuan meninggal karena kanker serviks. Ada 15.000 kasus baru per tahun dengan kematian 8000 orang pertahun. (Nurwijaya, 2010).

Terdapat beberapa faktor risiko yang berpengaruh terhadap terjadinya kanker serviks. Beberapa faktor yang diduga meningkatkan kejadian kanker serviks yaitu faktor sosiodemografis yang meliputi usia, status sosial ekonomi, dan faktor aktifitas seksual yang meliputi usia pertama kali melakukan hubungan seks, pasangan seks yang berganti-ganti, paritas, kurang menjaga kebersihan genital, merokok, riwayat penyakit kelamin, trauma kronis pada serviks, serta penggunaan kontrasepsi oral dalam jangka lama yaitu lebih dari 4 tahun (Diananda, 2007).

Menurut hasil penelitian Khasbiyah (2004) sebagian besar penderita kanker serviks memiliki paritas lebih dari 3. Kebanyakan penderita melakukan hubungan seksual yang pertama kali pada umur dibawah 20 tahun. Sedangkan menurut penelitian yang dilakukan Setyarini (2009) diketahui bahwa ada hubungan yang bermakna antara usia, usia pertama kali menikah, paritas dan penggunaan alat kontrasepsi oral dengan kejadian kanker serviks.

Di Provinsi Riau pada tahun 2009 sebanyak 131 orang $(2,97 \%)$ terdeteksi menderita kanker serviks. Dan terbanyak menyerang golongan umur 45-
64 tahun sebesar 44,3, 3\%. (Dinkes TK I Pekanbaru, 2009). Sedangkan dari data rekam medic RSUD Arifin Achmad Pekanbaru dalam 3 tahun terakhir didapatkan jumlah penderita kanker serviks yang terus bertambah dari tahun ketahun. Pada tahun 2008 penderita kanker serviks berjumlah 54 orang, meningkat menjadi 66 orang pada tahun 2009 dan pada tahun 2010 menjadi 110 orang ( RSUD Arifin Achmad, 2010). Tujuan penelitian ini adalah untuk mengetahui "Faktor-faktor yang Berhubungan dengan Kejadian Kanker Serviks di RSUD Arifin Achmad Pekanbaru tahun 2008-2010”.

\section{METODE}

Penelitian bersifat kuantitatif analitik observasional dengan menggunakan jenis desain studi kasus control. Kasus : Wanita penderita kanker serviks yang tercatat di rekam medis RSUD Arifin Achmad Pekanbaru. Kontrol : Wanita bukan penderita kanker serviks yang tercatat di rekam medis RSUD Arifin Achmad Pekanbaru. Sampel yang akan diambil menggunakan prosedur systematic random sampling. Dengan metode perhitungan ukuran sampel: $\alpha 5 \%, \beta$ $10 \%, \mathrm{OR}=2$, didapatkan 182 kasus dan 182 kontrol. Prosedur pengambilan sampel mulai bulan mei 2010, diurutkan kebelakang sampai mei 2008. Kasus dan control didapatkan dari catatan rekam medic RSUD Arifin Achmad Prov RIAU. Jenis data yang dikumpulkan adalah data sekunder dengan menggunakan daftar cheklis.

\section{HASIL}

\section{Analisis Univariat}

Diantara 8 variabel tidak ada variabel yang homogen (salah satu kategorinya mempunyai nilai < $20 \%$ ), sedangkan yang merupakan variabel beresiko (salah satu kategorinya $>50 \%$ ) yaitu variabel penggunaan kontrasepsi hormonal, paritas, ganti pasangan, usia pertama kali berhubungan seksual, usia, penyakit menular seksual, pendidikan dan pekerjaan.

\section{Analisis Bivariat}

Seluruh variabel independen (penggunaan kontrasepsi hormonal, paritas, ganti pasangan, usia pertama kali berhubungan seksual, usia, penyakit menular seksual, pendidikan dan pekerjaan ) memiliki hubungan yang signifikan terhadap kejadian kanker serviks.

\section{Analisis Multivariat}

Tabel 1. menunjukkan bahwa hasil analisis multivariat terakhir, Dari analisis multivariat ternyata variabel yang berhubungan bermakna dengan kejadian kanker serviks adalah paritas, usia pertama kali berhubungan seksual, pendidikan dan pekerjaan. Sedangkan variabel penggunaan kontrasepsi hormonal, penyakit menular seksual dan usia merupakan variabel confounding. 
Hasil analisis multifariat didapatkan odds ratio (OR) dari variabel pekerjaan adalah 9, 184 artinya wanita dengan pekerjaan berat lebih berisiko 9 kali menderita kanker serviks dibandingkan dengan wanita dengan pekerjaan ringan setelah dikontrol dengan variabel paritas, usia pertama kali berhubungan seksual, pendidikan dan pekerjaan. Secara sama dapat diinterprestasikan untuk variabel yang lain, semakin besar nilai exp (B) berarti semakin besar pengaruhnya terhadap variabel dependen yang dianalisis. Hal ini berarti pekerjaan paling besar pengaruhnya terhadap kejadian kanker serviks.

Table 1

Permodelan Multivariate Tahap Akhir

\begin{tabular}{|c|c|c|c|c|}
\hline \multirow[t]{2}{*}{ Variabel } & \multirow[t]{2}{*}{$\mathrm{p}$ value } & \multirow[t]{2}{*}{ OR } & \multicolumn{2}{|c|}{$\begin{array}{l}95 \% \text { CI. } \\
\text { For EXP (B) }\end{array}$} \\
\hline & & & Lower & Upper \\
\hline Paritas & 0,000 & 3,396 & 1,925 & 5,992 \\
\hline Usia pertamakali berhubungan seksual & 0,000 & 2,792 & 1,631 & 4,781 \\
\hline Pendidikan & 0,000 & 3,698 & 1,950 & 7,013 \\
\hline Pekerjaan & 0,000 & 9,184 & 5,346 & 15,779 \\
\hline Penggunaan kontrasepsi hormonal & 0,286 & 1,408 & ,751 & 2,638 \\
\hline Penyakit menular seksual & 0,042 & 1,894 & 1,023 & 3,509 \\
\hline Usia & 0,003 & 2,433 & 1,346 & 4,400 \\
\hline
\end{tabular}

\section{PEMBAHASAN}

\section{Relevansi dan Validitasi Data}

Hasil penelitian ini menunjukkan adanya relevansi data karena adanya kesesuaian antara data yang dikumpulkan dengan pencapaian tujuan khusus dan pembuktian hipotesis. Validitas eksternal pada penelitian ini tidak ada, validitas internal terdiri dari random error penelitian ini dengan sampel besar yang berjumlah 303 dan systematic error dimana terdapat bias informasi yang tidak dapat dihindari. Dalam penelitian ini terdapat variabel confounding yaitu penggunaan kontrasepsi hormonal, penyakit menular seksual dan usia, karena dalam analisis multivariat ditemui perubahan reabilitas risk $>10 \%$ yaitu variabel umur terhadap variabel paritas. Reliabilitas data dalam penelitian ini tidak dapat ditentukan karena pengumpulan data hanya dilakukan satu kali.

Tabel 2

Matriks Hubungan Sebab Akibat Variabel Independen dengan Kejadian Kanker Serviks di RSUD Arifin Achmad Provinsi Riau Tahun 2011

\begin{tabular}{|c|c|c|c|c|c|}
\hline \multirow[b]{2}{*}{ No } & \multirow[b]{2}{*}{ Kriteria } & \multicolumn{3}{|c|}{ Variabel Independent } & \multirow[b]{2}{*}{ Pekerjaan } \\
\hline & & Paritas & $\begin{array}{l}\text { Usia pertama } \\
\text { kali berhubungan } \\
\text { seksual }\end{array}$ & Pendidikan & \\
\hline & 1. Hubungan Temporal & + & + & + & + \\
\hline & 2. Plausibility & + & + & + & + \\
\hline & 3. Konsistensi & + & + & + & + \\
\hline & $\begin{array}{c}\text { 4. Kekuatan Asosiasi (OR } \\
\text { atau RR) }\end{array}$ & 3,396 & 2,792 & 3,698 & 9,184 \\
\hline & $\begin{array}{l}\text { 5. Dose } \\
\text { relationship }\end{array}$ & - & - & - & - \\
\hline & 6. Jenis desain Penelitian & - & - & - & - \\
\hline
\end{tabular}

Variabel yang Berhubungan dengan Kejadian Kanker Serviks

\section{Pekerjaan}

Teheru (1998) terdapat hubungan antara kanker serviks dengan pekerjaan, dimana wanita pekerja kasar seperti buruh, petani memperlihatkan 4 kali lebih mungkin terkena kanker serviks dibandingkan wanita pekerja ringan atau bekerja dikantor. Para wanita pekerja kasar 4 kali lebih mungkin terkena kanker serviks dibandingkan dengan wanita pekerja kantor atau pekerja ringan, mungkin karena standart kebersihan yang tidak baik pada umumnya faktor sosial ekonomi rendah cenderung memuali aktifitas seksual pada usia lebih muda (Teheru, 1998). Wanita pekerja kasar identik dengan status sosial ekonomi yang rendah biasanya dikaitkan dengan hygiene, sanitasi dan pemeliharaan kesehatan masih kurang. Pendidikan rendah, kawin usia muda, jumlah anak yang tinggi, pekerjaan dan penghasilan tidak tetap, serta faktor gizi yang kurang akan 
memudahkan terjadinya infeksi yang menyebabkan daya imunitas tubuh menurun sehingga menimbulkan risiko terjadinya kankser serviks (Teheru, 1998).

\section{Pendidikan}

Tingkat pendidikan dengan kejadian Kanker Serviks terdapat hubungan yang kuat, dimana kanker serviks cenderung lebih banyak terjadi pada wanita yang berpendidikan rendah dibanding wanita berpendidikan tinggi $(88,9)$. Tinggi rendahnya pendidikan berkaitan dengan tingkat sosio ekonomi, kehidupan seks dan kebersihan. Penelitian yang dilakukan Surbakti (2004) pendidikan mempunyai hubungan bermakna dengankejadian kakner serviks $\mathrm{OR}=2,012$ denngan kata lain penderita kanker serviks yang berpendidikan rendah merupakan faktor yang berisiko yang mempengaruhi terjadinya kanker serviks. Wanita yang berpendidikan rendah ada kemungkinan kurang begitu memperhatikan tentang kesehatan, terutama kesehatan yang ada kaitannya dengan kebersihan diri terutama kebersihan alat kelaminnya maka akan memiliki risiko untuk terkena kanker serviks (Aziz, 2002).

\section{Paritas}

Semakin tinggi risiko menderita kanker serviks pada wanita dengan banyak anak, apalagi dengan jarak persalinan yang terlalu pendek. Seorang perempuan yang sering melahirkan (banyak anak) termasuk golongan risiko tinggi untuk terkena penyakit kanker serviks. Dengan seringnya seorang ibu melahirkan, maka akan berdampak pada seringnya terjadi perlukaan di organ reproduksinya yang akhirnya dampak dari luka tersebut akan memudahkan timbulnya Human Papilloma Virus (HPV) sebagai penyebab terjadinya penyakit kanker serviks (Prayitno, 2006). Kanker serviks sering dijumpai pada wanita yang sering melahirkan anak. Kategori partus ini belum ada keseragaman tetapi menurut pakar angka berkisar antara 3- 5 kali partus. Green menemukan penderita kanker serviks adalah 7,9\% multi para dan $51 \%$ nulli para. Persalinan pervaginam yang tinggi menyebabkan angka terjadinya kanker serviks meningkat. Penelitian yang dilakukan oleh Setyarini (2009) tentang faktor-faktor yang berhubungan dengan kanker leher rahim di RSUD Moewardi Surakarta mempunyai hasil yang mendukung yaitu wanita dengan paritas $\geq 3$ kali lebih berisiko 5 kali menderita kanker serviks dibandingkan dengan wanita yang memiliki paritas $<3$ kali. Hasil penelitian Khasbiyah (2004) sebagian besar penderita kanker serviks memiliki paritas lebih dari 3. Penelitian dengan hasil yang serupa dilakukan oleh Harjono (2001) dan Arumugam (2010).

\section{Usia}

Makin muda seorang perempuan melakukan hubungan seksual, makin besar risiko yang harus ditanggung untuk mendapatkan kanker serviks dalam kehidupan selanjutnya karena pada usia muda sel epitel serviks belum bisa menerima rangsangan spermatozoa, Umumnya sel-sel mukosa baru matang setelah wanita berusia 20 tahun ke atas. (Rasjidi, 2008). Risiko kanker serviks akan meningkat pada pernikahan usia muda atau pertama kali koitus, yaitu pada umur 15-20 tahun atau pada belasan tahun serta period laten antara pertama kali koitus sampai terdeteksi kanker serviks selama 30 tahun. Menurut Aziz (2006), wanita di bawah usia 16 tahun menikah biasanya 10-12 kali lebih besar terserang kanker serviks daripada yang berusia 20 tahun ke atas. Penelitian Zuraedah (2001) didapatkan hasil yaitu menikah pada usia $<20$ tahun dianggap terlalu muda untuk melakukan hubungan seksual dan berisiko terkena kanker serviks 10-12 kali lebih besar daripada mereka yang menikah pada usia $>20$ tahun. Hal ini berkaitan dengan kematangan sel-sel mukosa pada serviks. Pada usia muda, sel-sel mukosa pada serviks belum matang. Artinya, masih rentan terhadap rangsangan sehingga tidak siap menerima rangsangan dari luar. Termasuk zat-zat kimia yang dibawa sperma. Karena masih rentan, sel-sel mukosa bisa berubah sifat menjadi kanker. Sifat sel kanker selalu berubah setiap saat yaitu mati dan tumbuh lagi.

\section{Variabel yang tidak Berhubungan dengan Kejadian Kanker Serviks}

\section{Ganti Pasangan}

Telaah pada berbagai penelitian epidemiologi kanker serviks menunjukkan hubungan yang kuat antara mitra seks, dan usia saat melakukan hubungan seks pertama kali dengan kanker serviks. Pada wanita yang memiliki 6 pasangan seks atau lebih akan lebih berisiko 1 pasangan seks. Risiko terkena kanker serviks akan meningkat pula wanita mempunyai 1 pasangan seks tetapi pria tersebut memiliki banyak pasangan seks atau yang mengidap kondiloma akuminatum (Aziz, 2002). Tetapi dalam penelitian ini hasil analisa multivariat tidak menemukan hubungan yang bermakna antara berganti pasangan dengan kejadian kanker serviks. Hal ini bisa saja terjadi apabila pasangan yang berganti pasangan melakukan hubungan seksual dengan cara yang aman. Misalnya dengan menggunakan kondom sehingga tidak terjadi penularan HPV pada pasangannya. (Arum, 2009).

\section{Variabel Confounding}

\section{Penggunaan Kontrasepsi Hormonal}

Penggunaan kontrasepsi hormonal lebih dari 4 atau 5 tahun dapat meningkatkan risiko terkena kanker serviks 1,5-2,5 kali. Beberapa penelitian menunjukkan bahwa kontrasepsi oral menyebabkan wanita sensitif terhadap HPV yang dapat menyebabkan adanya peradangan pada genitalia sehingga berisiko untuk terjadi kanker serviks (Hartmann, 2002). Menurut Manuaba (2004) salah satu sifat khas dari hormon 
esterogen adalah menimbulkan perlunakan pada serviks. Selain itu pemakaian kontasepsi hormonal dapat menurunkan jumlah kadar nutrient (Vitamin C, B12, B6, B2, asam folat dan Zinc) yang terlibat dalam imunitas. Tercatat bahwa $67 \%$ penderita kanker serviks mempunyai sedikitnya 1 kadar vitamin abnormal, 33\% terlihat multiple parameter nutrional abnormal (Emilia, 2010). Hasil analisa multivariat dalam penelitian ini bahwa selain berhubungan dengan kanker serviks, variabel penggunaan kontrasepsi hormonal juga berhubungan dengan paritas, usia pertama kali berhubungan seksual, usia, penyakit menular seksual, pendidikan dan pekerjaan.

\section{Penyakit Menular Seksual}

Wanita yang terkena penyakit akibat hubungan seksual berisiko terkena virus HPV, karena virus HPV diduga sebagai penyebab utama terjadinya kanker serviks sehingga wanita yang mempunyai riwayat penyakit kelamin berisiko terkena kanker serviks. Beberapa peneliti mengemukakan adanya hubungan anatar infeksi virus dengan terjadinya kanker servik, yaitu HPV, Virus Herpes simpleks (HSV-2), Virus Papiloma atau Virus Kondiloma Akuminata. Infeksi tersebut dapat terjadi melalui hubungan seksual yang prosesnya memakan waktu 2-30 tahun kemudian (Hacker, 2001). Hasil penelitian yang dilakukan oleh Melva (2008) dengan judul faktor-faktor yang mempengaruhi kejadian kanker leher rahim pad penderita yang datang berobat di RSUP H Adam Malik Medan yaitu wanita yang menderita penyakit menular seksual lebih berisiko 2 kali menderita kanker serviks dibandingkan dengan wanita yang tidak menderita kanker serviks.

\section{Usia}

Faktor yang mempengaruhi kanker serviks yaitu Usia $>35$ tahun mempunyai risiko tinggi terhadap kanker serviks. Semakin tua usia seseorang, maka semakin meningkat risiko terjadinya kanker laher rahim. Meningkatnya risiko kanker serviks pada usia lanjut merupakan gabungan dari meningkatnya dan bertambah lamanya waktu pemaparan terhadap karsinogen serta makin melemahnya sistem kekebalan tubuh akibat usia (Diananda, 2007). Menurut Aziz (2006), umumnya insidens kanker serviks sangat rendah di bawah umur 20 tahun dan sesudahnya menaik dengan cepat dan menetap pada usia 50 tahun. Menurut Riono (1990), kanker serviks terjadi pada wanita yang berumur lebih 40 tahun tetapi bukti statistik menunjukkan kanker serviks dapat juga menyerang wanita antara usia 20- 30 tahun (Riono, 1990). Selain berhubungan dengan kejadian kanker serviks, faktor usia berkaitan juga dengan paritas, usia pertama kali berhubungan seksual, pendidikan dan pekerjaan.

\section{KESIMPULAN}

Faktor risiko wanita dengan pekerjaan berat lebih beresiko menderita kanker serviks 9 kali dibandingkan dengan wanita yang memiliki pekerjaan ringan. Faktor risiko wanita yang berpendidikan rendah 4 kali lebih berisiko menderita kanker serviks dibandingkan dengan wanita yang berpendidikan tinggi. Faktor risiko wanita yang usia pertama kali berhubungan seksual kurang dari 20 tahun lebih berisiko 3 kali menderita kanker serviks dibandingkan dengan wanita yang usia pertama kali berhubungan seksual diatas 20 tahun. Faktor risiko wanita yang memiliki paritas $>3$ anak lebih berisiko 7 kali dibandingakn dengan wanita yang memiliki paritas < anak 3. Variabel yang tidak berhubungan sebab akibat dengan Kejadian Kanker Serviks adalah ganti pasangan dan Variabel yang confounding dengan kejadian kanker serviks adalah penggunaan kontrasepsi hormonal, penyakit menular seksual dan usia.

\section{REKOMENDASI}

\section{Pekerjaan}

Wanita yang memiliki pekerjaan berat dapat terhindar dari kanker serviks dengan cara melakukan skrining, yaitu dengan melakukan Pap's mear secara rutin minimal 1 tahun sekali. Dengan Pap's mear maka dapat dideteksi kondisi serviks, selain itu wanita dengan pekerjaan yang berat bisa dibarengi dengan pemberian informasi mengenai asupan gizi adekuat, istirahat yang cukup dan wanita tersebut harus dapat menjaga kebersihan genitalia agar terhindar dari infeksi kuman HPV.

\section{Pendidikan}

Tingkat Pendidikan wanita yang rendah tidak dapat diintervensi langsung oleh tenaga kesehatan oleh sebab itu yang hal bisa dilakukan terhadap wanita yang berpendidikan rendah adalah meningkatkan pengetahuan tentang kanker serviks melalui penyebaran informasi-informasi berupa penyuluhan kesehatan, brosur dan leaflet yang berkaitan dengan kanker serviks.

\section{Usia Pertama Kali Berhubungan Seksual}

Diberikan informasi agar para remaja putri agar dapat menunda usia pernikahan sampai usia 20 tahun, tidak pernah melakukan seks bebas, imunisasi kanker serviks sehingga kemungkinan terpapar dengan kuman HPV lebih kecil yang menjadi penyebab dari kanker serviks.

\section{Paritas}

Wanita usia reproduksi dianjurkan untuk melakukan kontrasepsi agar jumlah anak dapat dibatasi serta jarak kelahiran dapat diatur dengan baik, 
informasi tersebut bisa diberikan melalui penyuluhan, brosur ataupun leaflet.

\section{Penggunaan kontrasepsi hormonal \\ Wanita yang menggunakan kontrasepsi hormonal bisa diberi alternatif kontrasepsi non hormonal.}

\section{Penyakit menular seksual}

Penyakit menular seksual dapat dihindari dengan cara melakukan hubungan seksual yang aman, yaitu dengan satu pasangan yang sehat.

Usia

Wanita yang berusia $>35$ tahun dianjurkan melakukan skrining, yaitu dengan melakukan Pap's mear secara rutin minimal 1 tahun sekali.

\section{Ganti pasangan}

Pada penelitian ini ganti pasangan merupakan variabel yang tidak menunjukkan adanya hubungan sebab akibat dengan Kejadian Kanker Serviks. Oleh sebab itu perlu dilakukan penelitian lebih lanjut pada responden, tempat dan waktu yang berbeda.

\section{DAFTAR PUSTAKA}

Arum, dkk. (2009). Panduan Lengkap Pelayanan KB Terkini. Yogyakarta. Mitra Cendikia

Aziz, F M. (2006) Deteksi Dini Kanker, Skrining Dan Deteksi Dini Kanker Serviks. (Eds) Ramli Muchlis, Umbas Rainy, Panigoro S. Sonar Fakultas Kedokteran Universitas Indonesia Jakarta

Diananda, R. (2007). Mengenal Seluk Beluk Kanker. Yogyakarta. Katahati

Dinas Kesehatan Propinsi Riau (2010) Profil Dinas Kesehatan Provinsi Riau Tahun 2009

Emilia, O dkk. (2010) Bebas Ancaman Kanker Serviks. Yogyakarta Media Pressindo

Hacker, N. (2000). Cervical Cancer : Practical Gynecologic Oncology Fourth Edition

Harjono, M. (2001). Kanker Serviks Displasia Dapat Disembuhkan. Medika Jurnal No 3 Tahun XXVIII

Hartmann (2005) Mayo Clinic Guide to Women' Cancer : Breast and Gynecologic cancers. New York. Kensington Publishing

Khasbiyah. (2004). Beberapa Faktor Risiko Kanker Serviks Uteri (Studi Pada Penderita Kanker Serviks Uteri Di Rumah Sakit Dokter Kariadi Semarang Pada Bulan Agustus-September 2004). Tesis tidak diterbitkan. Diponegoro University.
Lapau, B. 2009. Prinsip Dan Metode Epidemiologi. Jakarta

Lapau, B. 2011. Metode Penelitian Kesehatan. Jakarta

Melva. 2008. Faktor-Faktor Yang Mempengaruhi Kejadian Kanker Leher Rahim Pad Penderita Yang Datang Berobat Di RSUP H Adam Malik Medan Tahun 2008. Tesis Tidak Diterbitkan. Universitas Sumatera utara

Notodiharjo, R. (2002). Reproduksi, Kontrasepsi, Dan Keluarga Berencana. Yogyakarta. Kanisius

Nurwijaya, H dkk. (2010). Cegah Dan Deteksi Dini Kanker Serviks. Jakarta P.T Elek Media Komputindo

Otto, S.E. (2001). Oncologi Nursing. 4th Ed. St Louis: Mosby Inc

Rasjidi, I. (2008). Manual Prakanker serviks. Edisi 1. Sagung Seto. Malang

Setyarini, E. (2009). Faktor- Faktor Yang Berhubungan Dengan Kejadian Kanker Leher Rahim Di Rsud Dr. Moewardi Surakarta. Skripsi tidak diterbitkan. Universitas Muhammadiyah Surakarta

Surbakti, E. (2008) Pendekatan Faktor risiko terhadap rancangan alternatif dalam penanggulangan kankerserviks di RS Pringadi Medan. Tesis tidak diterbitkan. Universitas Sumatera Utara

Teheru, (1998). Penanggulangan kanker terpadu paripurna (PKPT) di wilayah DKI Jakarta. Majalah ilmiah fakultas kedokteran USAKTI. Vol 17 No 2

Thomas, R. (2002) Buku Saku Ilmu Kandungan. Jakarta. Hipokrates

Zuraedah, E. (2001) Faktor-faktor risiko kanker leher rahim jenis karsinoma sel skuamosa di RSUPN Dr.Cipto mangunkusumo jakarta. Tesis tidak diterbitkan. Fakultas Kesehatan Masyarakat. Universitas Indonesia. 